\title{
INDOOR AIR PARTICLES IN OFFICE BUILDINGS WITH SUSPECTED INDOOR AIR PROBLEMS IN THE HELSINKI AREA
}

\author{
SANNA LAPPALAINEN, HEIDI SALONEN, KARI SALMI, and KARI REIJULA
}

Finnish Institute of Occupational Health, Helsinki, Finland

\begin{abstract}
Objectives: Airborne particle concentrations can be used as quality indicators of indoor environments. The previous lack of reference data has limited the use of particle measurements in office environments. The aim of this study was to describe the concentrations of airborne particles $(\geq 0.5 \mu \mathrm{m}$ and $\geq 5.0 \mu \mathrm{m})$ in 122 Finnish office buildings with suspected indoor air problems. Materials and Methods: The database consisted of indoor air and supply air particle samples collected in 2001-2006 from the Helsinki area. The particle concentrations ( $\geq 0.5 \mu \mathrm{m}$ and $\geq 5.0 \mu \mathrm{m})$ were measured in the indoor air (528 samples from 122 office rooms) and in the supply air (384 samples from 105 office rooms) with an optical particle counter. Airborne particle concentrations $\geq 0.5 \mu \mathrm{m}$ were categorized according to the efficiency of supply air filtration and health survey data. Results: The mean concentrations in the indoor air equaled 1900 particles/l and in the supply air 1300 particles/l. The efficiency of supply air filtration decreased the fine particles counts in both the indoor and supply air. The counts of large particles, $\geq 5.0 \mu \mathrm{m}$, were low in the indoor air. Airborne counts of $\geq 0.5 \mu \mathrm{m}$ particles (geometric mean) were statistically higher in the offices whose occupants had work-related symptoms (eye and/or upper respiratory symptoms or upper respiratory infections) than in the offices whose occupants had no such symptoms. However, the symptoms may also be linked to other indoor air problems or particle characteristics not studied in this work. Conclusions: This study indicates typical airborne particle levels ( $\geq 0.5 \mu \mathrm{m}$ and $\geq 5.0 \mu \mathrm{m})$ in Finnish office buildings with suspected indoor air problems. The results can be used to evaluate the quality of indoor environment, possible indoor air problems, and the need for additional investigations.
\end{abstract}

Key words:

Particle counts, Indoor air, Supply air, Office, Health effects

\section{INTRODUCTION}

Particles are ubiquitous in indoor and outdoor environments and the sources of particle matter (PM) are numerous. The main indoor environment sources of airborne particles include cooking, heating, cleaning and smoking tobacco. Indoor air may comprise particles such as fungal spores, bacteria, dry insect fragments, animal dander and particle matter from soil, cooking combustion, fireplaces and tobacco smoke [1-6]. Emissions from consumer products, building materials and printers can also act as significant aerosol sources in offices [7,8]. Moisture and mold damage may further increase airborne particle counts in buildings $[9,10]$.

Aerosol particles can be divided into coarse, fine and ultrafine ones. Particles with a diameter larger than $10 \mu \mathrm{m}$ are referred to as coarse and particles with a diameter larger than $2.5 \mu \mathrm{m}$, but less than $10 \mu \mathrm{m}$ are called fine particles. Ultrafine ones include particles with a diameter ranging from $0.001 \mu \mathrm{m}$ to $0.1 \mu \mathrm{m}$ [11]. Particulate air pollution seems to be responsible for most of the health effects, although the effects of gaseous pollutants cannot be

Received: April 3, 2012. Accepted: November 26, 2012.

Corresponding author: S. Lappalainen, Finnish Institute of Occupational Health, Arinatie 3A, 00370 Helsinki, Finland (e-mail: sanna.lappalainen@ttl.fi). 
ignored. Fine particles (aerodynamic diameter $<2.5 \mathrm{um}$ ) are capable of penetrating deep into the lungs, to the alveolar region, and seem to be more harmful than large particles [3,12].

Indoor exposure to airborne pollutants depends not only on emissions from various indoor sources, but also on outdoor pollutants supplied through ventilation and filtration. In urban areas, local aerosol sources include road and soil dust, automotive fuel combustion, industrial processes and energy production [3,13]. Many studies have shown that outdoor fine particle matter affects indoor air quality and personal exposure [14-16]. Lanki et al. (2007) detected in their project that outdoor sources (secondary sulfate, long range transport, oil combustion, traffic, crustal elements and sea salt) were responsible for about $66 \%$ of the indoor particle mass. Fine particles are mostly generated by burning and traffic. Particle counts and exposures have been shown to correlate highly with traffic levels [17]. Outdoor-to-indoor particle transport can also occur through cracks in the building shell and crevices in the windows and doors. However, ventilation systems are considered the critical factor in the outdoorto-indoor aerosol transport $[18,19]$.

Air pollution can consist of either harmful gases or aerosol particles. Many studies have shown a correlation between particulate pollution and several health indicators $[3,20,21]$. Elevated levels of particle air pollution have been associated with decreased lung function, increased respiratory symptoms such as coughing, shortness of breath, wheezing and asthma attacks, as well as chronic obstructive pulmonary disease, cardiovascular diseases and lung cancer. The size and composition of airborne particles are important factors in health issues. The size of particles determines the parts of the respiratory tract in which they are deposited, and the composition of particles may determine the way in which the respiratory tract reacts or how the whole body responds. Indoor environments and PM have also been associated with increased respiratory symptoms $[22,23]$.

The quality of indoor air is often evaluated using the results of particle measurements. However, very little data has been published regarding the concentrations of particles in the indoor air of offices in Nordic countries [24]. The aim of this study was to describe the concentration levels of particles ( $\geq 0.5 \mu \mathrm{m}$ and $\geq 5.0 \mu \mathrm{m}$ ) in the indoor air and supply air in office buildings with suspected indoor air problems causing adverse health effects. The study provides reference data for recognizing abnormal particle sources in the office environments. The results of particle concentrations were also classified according to the filtration level of the supply air. The hypothesis was that the quality of the supply air is the dominant factor in regard to the indoor air particle levels. The concentrations of particles $\geq 0.5 \mu \mathrm{m}$ in ambient air were also categorized as either associated with the work-related symptoms (repeated upper respiratory infections, eye or upper respiratory symptoms) or not associated with the work-related symptoms.

\section{MATERIALS AND METHODS}

The study was based on the measurement database of the Finnish Institute of Occupational Health (FIOH). It included 122 office buildings located in the Helsinki area in southern Finland. Helsinki is the capital of Finland with the population of about 1.3 million (i.e. with a lot of traffic). Particle concentrations were measured in the indoor air of 122 offices (in the indoor environment, at the height of $1.5 \mathrm{~m}$ ) and in the supply air of 105 offices (about $5 \mathrm{~cm}$ in front of the supply air valve). The corresponding numbers of samples were 528 and 384, respectively. The data included both office rooms and open-plan offices. The particle counts were always measured in the indoor air. In addition, the particle counts were measured in the supply air if the building had mechanical air supply. The efficiency of 
the supply air filters was recorded in some of the buildings (such information was not always available since this study was a retrospective one).

The particle concentrations were measured with the use of optical particle counters CI-550 (Climet Instruments Company, Redlands, CA, USA). CI counters are calibrated at least annually in accordance with ISO 10012-1 and the relevant parts of ISO 14644, Federal standards 209, ASTM F-50, and F-328 in the Climet Instruments Company. The measurements were taken in 2001-2006, mainly in autumn, winter and spring. The CI-550 measures particles in channels of six sizes (equal to or greater than $0.3,0.5,1,3,5$, and $10 \mu \mathrm{m}$ ) with a constant flow rate of 1.0 cubic foot per minute (CFM). The analyzed particle sizes in this study were $\geq 0.5 \mu \mathrm{m}$ and $\geq 5.0 \mu \mathrm{m}$. The collected samples were mostly short-term samples $(5 \times 1 \mathrm{~min})$, and each sample represented the mean value of these periods. Several samples were taken from each office and the results are presented as particle counts per liter. Some data was also classified according to the efficiency of filtration. Statistical tests were carried out using the SAS program package (version 9.1, SAS Inc., Cary, NC, USA).

The occupants worked in the offices eight hours a day, five days a week. The samples were taken during their normal working time. The office buildings were conventional as for their design, with a concrete framework, flat roof and several floors. Most of the buildings were equipped with a mechanical supply and exhaust ventilation system. The ventilation rates were originally planned to be in accordance with the National Building Code of Finland [25]. This means that the supply air (outdoor air) must flow at a minimum rate of $1.5 \mathrm{dm}^{3} / \mathrm{s}$ per $\mathrm{m}^{2}$. Most of the buildings had surface materials that were typical for office spaces: the floors were covered with a plastic carpet or linoleum, the walls and ceilings were made of concrete, and the ceilings were usually covered with some acoustic material.

All of the buildings included in this study had suspected indoor air problems, (e.g. moisture, thermal conditions, odors, dustiness or man-made vitreous fibers - MMVFs), and/or symptoms (mostly eye or upper respiratory irritative symptoms) were reported by the occupants of the buildings. Information regarding the problems mentioned above was provided by the industrial safety personnel (an industrial safety delegate or industrial safety officer) and occupational health care personnel (a company physician or nurse). A representative of the Property Maintenance $\&$ Management was responsible for information and maintenance of the building (e.g. ventilation and filtration). The studied buildings had no ongoing renovations (at least one year had elapsed since the last renovation). In addition, a walk-through inspection (an examination with sensory observations and limited measurements such as carbon dioxide measurement) did not reveal any clearly detectable reasons (e.g. mold damage) for indoor air problems, therefore different indoor air measurements were taken.

Before the walk-through investigations and measurements taken in the buildings, the industrial safety and occupational health care personnel received a questionnaire containing general questions concerning work-related symptoms. They interviewed the occupants and listed the complaints regarding the indoor air and environment, such as repeated upper respiratory infections and related eye or upper respiratory symptoms. Information on the possible building-related symptoms was also based on the visits of the occupational health care personnel (a company doctor or nurse). The industrial safety and health care personnel reported repeated irritation of the upper airways and/or eyes as well as repeated upper respiratory infections among several occupants in 51 and 13 buildings, respectively. These symptomatic office workers may also have had some other symptoms. No work-related symptoms were reported in 43 buildings. The data on the symptoms was not well documented in the remaining studied buildings $(\mathrm{N}=15)$, and therefore it was excluded from the "symptoms / no symptoms" data analysis. In this paper, the airborne particle concentrations in the offices 
with suspected indoor air problems are described and the results are classified according to the work-related symptoms and non-work-related symptoms.

\section{RESULTS}

Table 1 shows a summary of particle count measurements in the indoor air and supply air of the studied offices. The concentrations were rounded up to the next whole number. The range of fine particles, $\geq 0.5 \mu \mathrm{m}$, was very broad. However, typical particle levels could be detected in the office environments with suspected indoor air problems, while the geometric mean (GM) and the median of the concentrations had similar values: 1900 particles/l in the indoor air and 1300 particles/l in the supply air. The results indicated that the concentration of fine particles was commonly higher in the indoor air than in the supply air. In the supply air, the concentrations of particles $\geq 0.5 \mu \mathrm{m}$ equaled about $70 \%$ of that in the indoor air of the examined offices. The median (P50) concentration values of particles $\geq 5 \mu \mathrm{m}$ were about four times higher and the $\mathrm{P} 90$ values were about three times higher in the indoor air than in the supply air. The concentration values of particles $\geq 5 \mu \mathrm{m}$ were generally low in both the indoor and the supply air. The levels of particles $\geq 5 \mu \mathrm{m}$ were about three or four times higher in the indoor air than in the supply air, which demonstrates that large particles originate mainly from the indoor sources.

Table 2 classifies particle concentrations of $\geq 0.5 \mu \mathrm{m}$ in the indoor and supply air of the offices according to the efficiency of the supply air filtration. In Finland, the recommended efficiency of a supply air filter is F7 for office buildings, which means that the average efficiency for the removal of $0.4 \mu \mathrm{m}$ particles is $80-90 \%$. Compared with the results of the airborne particle concentrations in Table 1 (data based on the mixture of filters), the supply air filtration with F7 efficiency reduces fine particle counts by about $40 \%$ and $20 \%$ as regards the typical levels in the supply and indoor air (Table 2), respectively. The results show that in this study, the main source of fine particles was the outdoor air. Table 2 demonstrates that if filtration less efficient than F7 is used, for example F5 (average efficiency removal of $0.4 \mu \mathrm{m}$ particles on the level of 50-60\%), the particle counts in the supply air double and are even higher in the indoor air. The supply air did not generally include large particles (F7 filtration).

The particle counts in the indoor and supply air were classified according to the work-related symptoms and the results are shown in Table 3. The particle counts were the lowest in the indoor and supply air of the office buildings where no work-related symptoms were reported. On the other hand, the particle counts were the highest in the indoor and supply air of the office buildings in which upper respiratory

Table 1. Summary of particle count measurements in the examined office environments

\begin{tabular}{lrcrc}
\hline & \multicolumn{3}{c}{ Concentration of particles (particles/liter) } \\
\cline { 2 - 5 } \multicolumn{1}{c}{ Parameters } & \multicolumn{2}{c}{$\begin{array}{c}\text { indoor air } \\
(\mathrm{N}=528)\end{array}$} & \multicolumn{2}{c}{$\begin{array}{c}\text { supply air } \\
\text { (N = 384) }\end{array}$} \\
\cline { 2 - 5 } & $\geq 0.5 \mu \mathrm{m}$ & $\geq 5.0 \mu \mathrm{m}$ & 1300 & $\geq 5.0 \mu \mathrm{m}$ \\
\hline Geometric mean & 1900 & 25 & 21600 & 5 \\
Standard deviation & 3100 & 45 & 1300 & 5 \\
Median (P50) & 1900 & 20 & 5500 & 20 \\
P90 & 7000 & 65 & 212700 & 250 \\
Maximum & 27300 & 360 &
\end{tabular}

$\mathrm{N}$ - air samples. Indoor air samples were taken from 122 office rooms and supply air samples from 105 office rooms. 
Table 2. Particle counts in the indoor and supply air of the office rooms classified according to the efficiency of the supply air filtration

\begin{tabular}{|c|c|c|c|c|c|c|}
\hline \multirow{3}{*}{ Parameters } & \multicolumn{6}{|c|}{ Concentration of $\geq 0.5 \mu \mathrm{m}$ particles (particles/liter) } \\
\hline & \multicolumn{3}{|c|}{ indoor air } & \multicolumn{3}{|c|}{ supply air } \\
\hline & $\begin{array}{c}\text { F5 } \\
(\mathrm{N}=31)\end{array}$ & $\begin{array}{c}\mathrm{F} 6 \\
(\mathrm{~N}=18)\end{array}$ & $\begin{array}{c}\mathrm{F} 7 \\
(\mathrm{~N}=47)\end{array}$ & $\begin{array}{c}\text { F5 } \\
(\mathrm{N}=14)\end{array}$ & $\begin{array}{c}\mathrm{F} 6 \\
(\mathrm{~N}=15)\end{array}$ & $\begin{array}{c}\mathrm{F} 7 \\
(\mathrm{~N}=27)\end{array}$ \\
\hline Geometric mean & 3600 & 1500 & 1500 & 1600 & 1400 & 840 \\
\hline Standard deviation & 4200 & 1100 & 1000 & 1100 & 1200 & 390 \\
\hline Median (P50) & 3400 & 2200 & 1600 & 1300 & 2400 & 860 \\
\hline $\mathrm{P} 90$ & 8500 & 3800 & 2800 & 3100 & 3600 & 1600 \\
\hline Maximum & 21600 & 3900 & 5500 & 4000 & 3600 & 1800 \\
\hline
\end{tabular}

$\mathrm{N}$ - air samples. F5-F7 - the efficiency of the air supply filtration. Indoor air samples were taken from 25 buildings and supply air samples from 20 buildings.

infections were reported. The geometric mean concentration of particles $\geq 0.5 \mu \mathrm{m}$ in the indoor air was statistically higher $(p=0.007)$ in the offices with work-related symptoms among the employees (eye and/or upper respiratory symptoms as well as upper respiratory infections) than in the offices with no work-related symptoms among the staff. The statistical difference $(p=0.05)$ was also noted in the geometric mean concentration of particles $\geq 0.5 \mu \mathrm{m}$ in the supply air between the offices whose occupants reported upper respiratory infections and offices whose occupants reported no work-related symptoms.

\section{DISCUSSION}

The quality of indoor air is often evaluated using airborne particle counts in clean rooms and associated controlled environments [26]. A broad spectrum of quality factors is also needed to evaluate the indoor environment of office buildings. Airborne particles are the subject of growing interest in the evaluation of air quality in indoor environments. Particles in the indoor air can be controlled by several technical and operational factors, out of which the efficiency of the supply air filtration is the most important

Table 3. Particle counts in the indoor and supply air of office rooms classified as having possible association with work-related symptoms

\begin{tabular}{|c|c|c|c|c|c|c|}
\hline \multirow[b]{3}{*}{ Parameters } & \multicolumn{6}{|c|}{ Concentration of $\geq 0.5 \mu \mathrm{m}$ particles (particles/liter) } \\
\hline & \multicolumn{3}{|c|}{ indoor air } & \multicolumn{3}{|c|}{ supply air } \\
\hline & $\begin{array}{c}\text { eye and/or upper } \\
\text { respiratory } \\
\text { symptoms } \\
(\mathrm{N}=192)\end{array}$ & $\begin{array}{l}\text { upper respiratory } \\
\text { infections } \\
(\mathrm{N}=55)\end{array}$ & $\begin{array}{c}\text { no work-related } \\
\text { symptoms } \\
(\mathrm{N}=209)\end{array}$ & $\begin{array}{c}\text { eye and/or upper } \\
\text { respiratory } \\
\text { symptoms } \\
(\mathrm{N}=144)\end{array}$ & $\begin{array}{l}\text { upper respiratory } \\
\text { infections } \\
(\mathrm{N}=23)\end{array}$ & $\begin{array}{c}\text { no work-related } \\
\text { symptoms } \\
(\mathrm{N}=146)\end{array}$ \\
\hline Geometric mean & 2000 & 2300 & 1600 & 1400 & 1900 & 1200 \\
\hline Standard deviation & 3600 & 4400 & 2200 & 34800 & 3900 & 2500 \\
\hline Median (P50) & 2000 & 2000 & 1600 & 1100 & 2300 & 1200 \\
\hline $\mathrm{P} 90$ & 7700 & 6700 & 5100 & 7800 & 4500 & 4700 \\
\hline Geometric mean & 2000 & 2300 & 1600 & 1400 & 1900 & 1200 \\
\hline
\end{tabular}

$\mathrm{N}$ - air samples. Indoor air samples were taken from 107 buildings and supply air samples from 91 buildings. 
one [18]. Therefore, the need for reference data concerning airborne particle counts is obvious. This study described the typical concentration levels of particles ( $\geq 0.5 \mu \mathrm{m}$ and $\geq 5.0 \mu \mathrm{m}$ ) in the indoor and supply air in office buildings with suspected indoor air problems. The particle results reflect the general quality of the indoor air in those buildings and can be used in assessing the need for additional investigations. The particle counts in the indoor air vary to a great extent and, therefore, these results coming from short measurement periods can be used as preliminary particle levels in office buildings with suspected indoor air problems. Some studies have presented that the concentration levels in case of personal exposure are higher than those of indoor or outdoor particles measured for stationary samples $[27,28]$.

The mean values were 1900 particles/l in the indoor air and 1300 particles $/ 1$ in the supply air. In this study, the particle concentrations were generally higher in the indoor air than those reported earlier in the study concerning an office in Espoo, Finland's second biggest city [24]. The particle counts in the indoor air were higher in schools and hospitals situated abroad than in the present study, but the measurement range was also wider (mostly $0.02-1 \mu \mathrm{m}$ ) and, therefore, the direct comparison is not possible [29-32]. The counts of $\geq 0.5 \mu \mathrm{m}$ particles in the indoor air were lower (excluding special rooms, e.g. the plaster room) in the study involving Finnish hospitals than in the offices examined in this study [33]. Other indoor air PM studies in Finnish offices were based on the mass concentration and the total particle concentrations [16,34]. Finnish regulations of the indoor environment require that particle concentrations should be distinctly lower in the supply air than in the indoor air. Many studies, including one of an office building in Helsinki, have revealed that indoor particle concentrations are greatly dependent on outdoor concentrations [2,16,34]. This means that filtration of air pollutants during the transport of air from the outdoors to the indoors is an important factor in the indoor air quality.
The filtration efficiency of ventilation air cleaners is highly dependent on the particle size exceeding the 0.01 to $3 \mu \mathrm{m}$ diameter size range (fine particles are filtered from the outdoor air only when filtration is highly efficient). Other important factors influencing the efficiency include the flow rate and the dust load present on the air filter [35]. High efficiency filters significantly reduce the indoor mass concentrations of particles [36], and filtration of the supply air is the main control factor as regards the airborne particle concentrations in this study. Efficient filtration of the supply air (F7) decreased particle counts in the indoor and the supply air to 1500 and 840 particles/l, respectively. The mean levels of particles $\geq 5 \mu \mathrm{m}$ were 20 particles/l in the indoor air and 5 particles/l in the supply air. The results of particle counts in the indoor air were slightly higher than those reported earlier for Finnish offices [24]. F7 filtration should stop any particles $\geq 5 \mu \mathrm{m}$. The results may be associated with the instrument (CI 500/550) or measurement biases. The sample was taken from the spot about $5 \mathrm{~cm}$ in front of the supply air valve.

The range of airborne particle counts over time was broad in the indoor air examined in this study. The variation was more significant in the supply air than in the indoor air, indicating a high PM variation in the outdoor air. Thus, long sampling time or numerous samples are recommended from both the indoor and outdoor air. Earlier studies had also shown that in the office indoor particle levels, fine particles in particular follow the temporal and spatial variation in the outdoor particle concentration and indoor sources $[14,15]$. In school studies, it was also indicated that the indoor concentrations of the finest particles closely tracked the outdoor ones, but the correlation was not noticed for larger particles [29]. In addition, the concentrations of indoor particles depend on potential sources for particle contribution from the inside and outside of the buildings, the ventilation type, the air change rates, the efficiency of the air filtration system in use, building 
characteristics, human activities and the physical activity of the occupants [37].

Luoma and Batterman (23) found out, in their study examining Finnish offices, that occupant activities such as walking past or visiting the monitoring site accounted for $24-55 \%$ of the variation of $1-25 \mu \mathrm{m}$ diameter particle number concentrations. Airborne particles settle on the majority of building surfaces, but human activity and cleaning can resuspend the settled particles, thereby increasing particle concentrations in the indoor air. For example, movement such as walking through a room and cleaning can cause resuspension. Particulate resuspension from clothing has also been detected. Resuspension rates are higher for coarse particles than for fine and ultrafine particles, due to adhesion and detachment forces [38].

Apart from the supply air, factors affecting the indoor particle counts were not controlled in this study. The aim was to describe typical particle levels in the indoor air of offices with suspected indoor air problems that were mainly equipped with sophisticated ventilation systems. Photocopiers and printers are also sources of indoor particles in office environments. It has been reported that dry-process photocopiers can produce elevated concentrations of respirable particles, and laser printers, while in operation, can produce high PM10 concentrations [8,39,40]. Reactions between indoor air pollutants can also increase the size of particles or even form new particles. Secondary organic particles are produced from ozone and volatile organic compounds (VOCs) emitted by e.g. printers or air cleaners. Chemical reactions (e.g. involving terpenes and ozone) may result in the formation of ultrafine particles [41,42].

A number of studies have shown that exposure to fine particulate air pollution can lead to various adverse health effects in humans. The most serious health effects have been associated with combustion- and traffic-generated particles in the outdoor air [15,43-46]. Indoor PM has also been associated with increased respiratory symptoms [22,23]. In this study, airborne counts of particles $\geq 0.5 \mu \mathrm{m}$ (GM) were statistically higher in the offices whose occupants reported work-related symptoms (eye and/or upper respiratory symptoms as well as upper respiratory infections) than in the offices whose occupants reported no workrelated symptoms. A part of the airborne particulate matter is of biological origin - estimation of the total particle mass concentration varies from $<1 \%$ to $37 \%$ depending on the size of the particles studied [47,48]. For instance, fungi can affect human health through infections, allergic or hypersensitivity reactions, and irritant reactions [49]. A possible link between the irritation symptoms and the particle-related findings in this study remains unclear, because no other particle characteristics, except numbers, were studied. In addition, the health data was based only on interviews conducted by the industrial safety and health care personnel. Therefore, more studies are needed to clarify the role of fine particles in the cases of possible indoor air problems in office buildings.

Indoor particles may carry irritant, toxic and allergenic pollutants [12]. The present study did not analyze the composition of particles. However, indoor air and supply air may also include MMVFs, such as rock or stone wool, slag wool, or glass fibers. Fiber dust particles usually have a length of $>5 \mu \mathrm{m}$ and a diameter of $<3 \mu \mathrm{m}$. The length/ diameter ratio for fibers is typically $3: 1$, but MMVFs may also include respirable airborne particles. Sound and heat insulations of ventilation equipment and acoustic ceiling boards are possible sources of fibers. It has been suggested that MMVFs may be responsible for itchy skin and irritation of the upper respiratory tract and eyes, as well as for outbreaks of 'office eye syndrome' and 'collective dermatitis' [50-53].

\section{CONCLUSION}

This study described typical particle counts of particles $\geq 0.5 \mu \mathrm{m}$ and $\geq 5.0 \mu \mathrm{m}$ in the indoor and supply air of office buildings with suspected indoor air problems. 
The data regarding the particle concentrations can be used to evaluate the general indoor air quality level in relatively modern Finnish office buildings. Clearly, higher levels of airborne particles may indicate an indoor air problem, abnormal particle sources, and a need for additional investigations. The present results also support the conclusion that efficient filtration of the supply air (F7) decreases particle counts in the indoor and supply air. In addition, statistically higher airborne particle counts were detected in the offices whose occupants reported workrelated symptoms than in the offices whose occupants experienced no such symptoms. The association with possible health effects and airborne particle counts remains unclear since the control of numerous factors affecting the present research frame was very limited in this study. The data shows, nevertheless, the average levels of exposure to particles in the working environment of Finnish offices.

\section{ACKNOWLEDGEMENTS}

The authors warmly thank Henri Riuttala for his skilful statistical assistance, the indoor air researchers of the Finnish Institute of Occupational Health in Helsinki for their excellent field investigations, and Rauno Holopainen, DSc (Tech.) for his valuable comments on this article.

\section{REFERENCES}

1. Gold DR. Indoor air pollution. Clin Chest Med 1992;13(2): 215-29.

2. Wallace L. Indoor particles: a review. J Air Waste Manag Assoc 1996;46(2):98-126.

3. Morawska L, Zhang JJ. Combustion sources of particles. 1. Health relevance and source signatures. Chemosphere 2002;49(9):1045-58.

4. Toivola M, Alm S, Nevalainen A. Viable fungi and bacteria in personal exposure samples in relation to microenvironments. J Environ Monit 2004;6(2):113-20.
5. Koistinen KJ, Edwards RD, Mathys P, Ruuskanen J, Kunzli N, Jantunen MJ. Sources of fine particulate matter in personal exposures and residential indoor, residential outdoor and workplace microenvironments in the Helsinki phase of the EXPOLIS study. Scand J Work Environ Health 2004;30 Suppl 2:36-46.

6. Paufler P, Gebel T, Dunkelberg H. Quantification of house dust mite allergens in ambient air. Rev Environ Health 2001;16(1):65-80.

7. Tichenor BA, Mason MA. Organic emissions from consumer products and building materials to the indoor environment. Japca 1988;38(3):264-8.

8. He C, Morawska L, Taplin L. Particle emission characteristics of office printers. Environ Sci Technol 2007;41(17):6039-45.

9. Huttunen K, Rintala H, Hirvonen MR, Vepsäläinen A, Hyvärinen A, Meklin T, et al. Indoor air particles and bioaerosols before and after renovation of moisture-damaged buildings: The effect on biological activity and microbial flora. Environ Res 2008;107(3):291-8.

10. Salonen H, Lappalainen S, Lindroos O, Harju R, Reijula K. Fungi and bacteria in mould-damaged and non-damaged office environments in a subarctic climate. Athmos Environ 2007;41:6797-807.

11. Hinds WC. Aerosol Technology. Properties, behavior, and measurement of airborne particles. 2nd ed. New York: WileyInterscience; 1999. p. 483.

12. Bernstein JA, Alexis N, Bacchus H, Bernstein IL, Fritz P, Horner E, et al. The health effects of non-industrial indoor air pollution. J Allergy Clin Immunol 2008;121(3):585-91.

13. Vallius M, Janssen NA, Heinrich J, Hoek G, Ruuskanen J, Cyrys J, et al. Sources and elemental composition of ambient PM(2.5) in three European cities. Sci Total Environ 2005;337(1-3):147-62.

14. Cyrys J, Pitz M, Bischof W, Wichmann HE, Heinrich J. Relationship between indoor and outdoor levels of fine particle mass, particle number concentrations and black smoke under different ventilation conditions. J Expo Anal Environ Epidemiol 2004;14(4):275-83. 
15. O'Connell S, Au-Yeung HK, Gregory CJ, Matthews IP. Outdoor and indoor respirable air particulate concentrations in differing urban traffic microenvironments. J Toxicol Environ Health A. 2008;71(16):1069-72.

16. Janssen NA, de Hartog JJ, Hoek G, Brunekreef B, Lanki T, Timonen KL, et al. Personal exposure to fine particulate matter in elderly subjects: relation between personal, indoor, and outdoor concentrations. J Air Waste Manag Assoc 2000;50(7):1133-43.

17. Lanki T, Ahokas A, Alm S, Janssen NA, Hoek G, de Hartog JJ, et al. Determinants of personal and indoor PM2.5 and absorbance among elderly subjects with coronary heart disease. J Expo Sci Environ Epidemiol 2007;17(2):124-33.

18. Jamriska M, Morawska L, Clark BA. Effect of ventilation and filtration on submicrometer particles in an indoor environment. Indoor Air 2000;10(1):19-26.

19. Parker JL, Larson RR, Eskelson E, Wood EM, Veranth JM. Particle size distribution and composition in a mechanically ventilated school building during air pollution episodes. Indoor Air 2008;18(5):386-93.

20. COEHA. A committee of the environmental and occupational health assembly of the American thoracic society. Am J Respir Crit Care Med 1995;155(4):1376-83.

21. Dockery DW. Health effects of particulate air pollution. Ann Epidemiol 2009;19(4):257-63.

22. Simoni M, Scognamiglio A, Carrozzi L, Baldacci S, Angino A, Pistelli F, et al. Indoor exposures and acute respiratory effects in two general population samples from a rural and an urban area in Italy. J Expo Anal Environ Epidemiol 2004;14 Suppl 1:S144-52.

23. Simoni M, Carrozzi L, Baldacci S, Scognamiglio A, di Pede F, Sapigni T, et al. The Po River Delta (North Italy) indoor epidemiological study: effects of pollutant exposure on acute respiratory symptoms and respiratory function in adults. Arch Environ Health 2002;57(2):130-6.

24. Luoma M, Batterman SA. Characterization of particulate emissions from occupant activities in offices. Indoor Air 2001;11(1):35-48.
25. Finnish Ministry of the Environment. National Building Code of Finland, D2. Indoor Climate and Ventilation in Buildings, Regulations and Guidelines. Helsinki: Finnish Ministry of the Environment; 2003 [in Finnish].

26. EN ISO 14644-1. Cleanrooms and associated controlled environments - Part 1: Classification of air cleanliness. European Standard; 1999.

27. Toivola M, Alm S, Reponen T, Kolari S, Nevalainen A. Personal exposures and microenvironmental concentrations of particles and bioaerosols. J Environ Monit 2002;4(1): 166-74.

28. Jantunen M, Hänninen O, Koistinen K, Hasmin JH. Fine PM measurements: personal and indoor air monitoring. Chemosphere 2002;49:993-1007.

29. Blondeau P, Iordache V, Poupard O, Genin D, Allard F. Relationship between outdoor and indoor air quality in eight French schools. Indoor Air 2005;15(1):2-12.

30. Cox-Ganser JM, Rao CY, Park JH, Schumpert JC, Kreiss K. Asthma and respiratory symptoms in hospital workers related to dampness and biological contaminants. Indoor Air 2009;19(4):280-90.

31. Weber S, Kullman G, Petsonk E, Jones WG, Olenchock S, Sorenson W, et al. Organic dust exposures from compost handling: case presentation and respiratory exposure assessment. Am J Ind Med 1993;24(4):365-74.

32. Guo H, Morawska L, He C, Zhang YL, Ayoko G, Cao M. Characterization of particle number concentrations and PM2.5 in a school: influence of outdoor air pollution on indoor air. Environ Sci Pollut Res Int 2010;17(6):1268-78.

33. Lappalainen S, Holopainen R, Korhonen P, Hellgren U, Lindroos O, Palomäki E, et al., editors. Microbial aspects and particle counts in Finnish hospital environments Ventilation 2009, the 9th International Conference on Industrial Ventilation. Paper no: 1135 (cd); 2009; Zurich.

34. Koponen I, Asmi A, Keronen P, Puhto K, Kulmala M. Indoor air measurement campaign in Helsinki, Finland 1999 the effect of outdoor pollution on indoor air. Atmos Environ 2000;35:1465-77. 
35. Hanley JT, Ensor DS, Smith DD, Sparks LE, editors. Fractional aerosol filtration efficiency of in-duct ventilation air cleaners. Indoor Air '90. The 5th International Conference on Indoor Air Quality and Climate; 1994 July 29 - August 3; Toronto Canada. Inc., 2344 Haddington Crescent. 1994.

36. Fisk WJ, Faulkner D, Palonen J, Seppänen O. Performance and costs of particle air filtration technologies. Indoor Air 2002;12(4):223-34.

37. Molhave L, Kjaergaard SK, Attermann J. Respiratory effects of experimental exposure to office dust. Indoor Air 2004;14(6):376-84.

38. Thatcher TL, Layton D. Deposition, resuspension and penetration of particles within residence Atmos Environ 1995;29:1487-97.

39. Brown SK. Assessment of pollutant emissions from dry-process photocopiers. Indoor Air 1999;9(4):259-67.

40. Lee SC, Lam S, Fai HK. Characterization of VOCs, ozone, and PM10 emissions from office equipment in an environmental chamber. Build Environ 2001;36:837-42.

41. Weschler CJ, Shields HC. Experiments probing the influence of air exchange rates on secondary organic aerosols derived from indoor chemistry Atmos Environ 2003;37:5621-31.

42. Wainman T, Zhang J, Weschler CJ, Lioy PJ. Ozone and limonene in indoor air: A source of submicron particle exposure. Environ Health Perspect 2000;108(12):1139-45.

43. Pope CA, 3rd, Burnett RT, Thurston GD, Thun MJ, Calle EE, Krewski D, et al. Cardiovascular mortality and long-term exposure to particulate air pollution: epidemiological evidence of general pathophysiological pathways of disease. Circulation 2004;109(1):71-7.

44. Pope CA, 3rd, Burnett RT, Thun MJ, Calle EE, Krewski D, Ito K, et al. Lung cancer, cardiopulmonary mortality, and long-term exposure to fine particulate air pollution. JAMA 2002;287(9):1132-41.

45. Forbes LJ, Patel MD, Rudnicka AR, Cook DG, Bush T, Stedman JR, et al. Chronic exposure to outdoor air pollution and diagnosed cardiovascular disease: meta-analysis of three large cross-sectional surveys. Environ Health 2009;8:30. DOI: 10.1186/1476-069X-8-30.

46. Schwela D. Air pollution and health in urban areas. Rev Environ Health 2000;15(1-2):13-42.

47. Toivola M, Nevalainen A, Alm S. Personal exposures to particles and microbes in relation to microenvironmental concentrations. Indoor Air 2004;14(5):351-9.

48. Matthias-Maser S, Jaenicke R. Examination of atmospheric bioaerosol particles with radii $>0.2 \mu \mathrm{m}$. J Aerosol Sci 1994;25:1605-13.

49. Bush RK, Portnoy JM, Saxon A, Terr AI, Wood RA. The medical effects of mold exposure. J Allergy Clin Immunol 2006;117(2):326-33.

50. Schneider T, Lundqvist G. Man-made mineral fibers in the indoor, non-industrial environment. Build Environ 1986;21: 129-33.

51. Schneider T. Man-made mineral fibers and other fibers in the air and in settled dust. Environ Int 1986;12:61-5.

52. Vallarino J, Spengler JD, Buck R, Dilwali KM. Quantifying synthetic vitreous fiber surface contamination in office buildings. AIHA J (Fairfax, Va) 2003;64(1):80-7.

53. Vallarino J. Fibers. In: Spengler JD, Samet JM, McCarthy JF, editors. Indoor Air Quality Handbooks. New York: McGrawHill; 2000. p. 37.31-37.22.

This work is available in Open Access model and licensed under a Creative Commons Attribution-NonCommercial 3.0 Poland License - http://creativecommons.org/ licenses/by-nc/3.0/pl/deed.en. 